\title{
Perspectives of Preservice Teachers on the Statements Related to Preservice Teachers and Competence of Lecturers
}

\author{
Ihsan Nuri DEMİREL ${ }^{1}$ æ \\ Mehmet TEYFUR ${ }^{2}$ \\ Ismail ÇELİK ${ }^{3}$ \\ Serdar SAFALI ${ }^{4}$ \\ Alican KAYA ${ }^{5}$
}

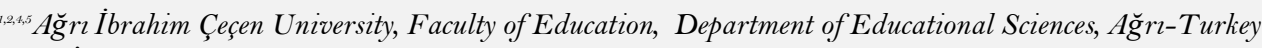
'A $\breve{g r l}$ İbrahim Çeçen University, Faculty of Education, Department of Preservice Education, A $\breve{g r}$ r-Turkey

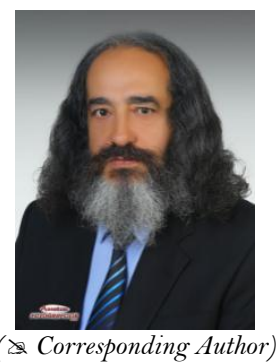

\begin{abstract}
This study aims to find out the attitude of preservice teachers of Ağrı İ.Ç. University Faculty of Education who study at the Department of Elementary Turkish Education to the statements related to preservice teachers and competence of lecturers. A-) The statements related to preservice teachers includes following statements: "Productivity of the courses taken in the school enable them to understand the qualifications that a teacher must have.", "Students take advantages of the education process which brings them sufficient teaching experience", "During their education, students experience many fascinating features related to teaching professions which they haven't seen before.", "Opportunities and facilities that the students have in the school let them have rich variety of experiences related to communication with people.", "The students who have thought that they couldn't be teacher understand they are in wrong to assume it after they experience teaching." B-) The statements related to competence of lecturers includes following statements: "Lecturers have enough professional competence since they have received decent undergraduate education.", "Lecturers can convey their knowledge to students by showing their class related to class management and employing different methods to teach since they don't teach the lessons with the exception of their professional fields.", "Lecturers can plan the teachinglearning process successfully thanks to their professional teaching knowledge.", "Scientific dignity that the lecturers have thanks to their competence makes them reach the exemplary positions.", "The high level of service delivery qualifications which the lecturers have thanks to their competence makes the students apply their knowledge to real life." A questionnaire which includes questions related to A-) the statements related to preservice and $\mathrm{B}-$ ) the statements related to competence of lecturers is conducted to determine the attitudes of preservice teachers towards. A) The statements related to preservice teachers and B-) The statements related to competence of lecturers. The sample for the research is composed of 121 preservice teachers of Ağrı İ.Ç. University Faculty of Education who study at the Department of Elementary Turkish Education. According to the findings of the research; it is seen that the preservice teachers have answered the questions containing information on $\mathrm{A}-$ ) the statements related to preservice and $\mathrm{B}-$ ) the statements related to competence of lecturers with variable rates. The results which are mentioned above make it possible to come to that conclusion that preservice teachers have responded to questionnaire which is reliable according to its Cronbach's Alpha value $(\alpha=0.91)$ in varying ratios (Field, 2013).
\end{abstract}

Keywords: The statements related to preservice teachers, The statements related to competence of lecturers.

Citation | Ihsan Nuri DEMİREL; Mehmet TEYFUR; Ismail ÇELIK; Serdar SAFALI; Alican KAYA (2018). Perspectives of Preservice Teachers on the Statements Related to Preservice Teachers and Competence of Lecturers. Journal of Education and eLearning Research, 5(3): 185-192.

History:

Received: 30 April 2018

Revised: 3 July 2018

Accepted: 5 September 2018

Accepted: 5 September 2018

Published: 10 October 2018
Licensed: This work is licensed under a Creative Commons

Licensed: This work is lice

Publisher:Asian Online Journal Publishing Group
Contribution/Acknowledgement: All authors contributed to the conception and design of the study.

Funding: This study received no specific financial support

Competing Interests: The authors declare that they have no conflict of interests.

Transparency: The authors confirm that the manuscript is an honest, accurate, and transparent account of the study was reported; that no vital features of the study have been omitted; and that any discrepancies from the study as planned have been explained.

Ethical: This study follows all ethical practices during writing. 


\section{Contents}

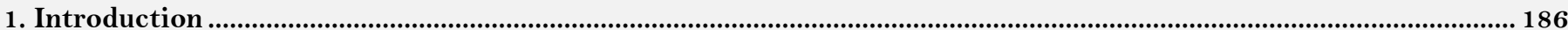

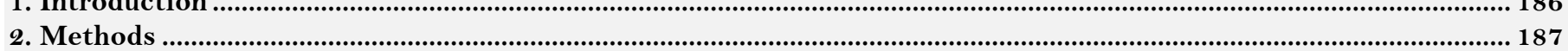

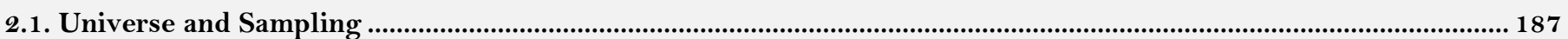

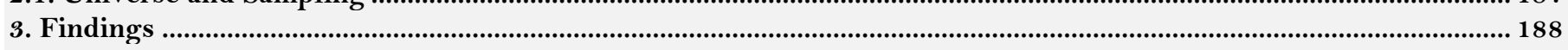

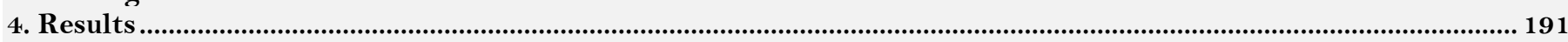

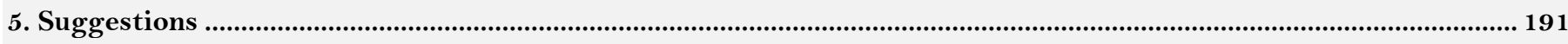

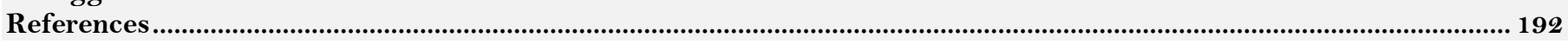

\section{Introduction}

It can be said that the courses which are taken in the school is really important when the topic is analyzed from the viewpoint of the following statement: "Productivity of the courses taken in the school enable them to understand the qualifications that a teacher must have." Quantitative or qualitative productivity in the education is crucial. Creating well-qualified educational planning comes with productivity in education. Similarly, a practical educational planning must be created to train preservice teachers in a required way. There are many studies emphasizing the importance of high-level thinking skills in human life (Yildirim and Haşıloğlu, 2018). In order to strengthen the features of the teachers that mentioned in the statements, make the following definition of the education more close to life "education is the process in which the person make desired and designed facilities related to their behaviors by the help of their own experiences."

When the topic is analyzed from the viewpoint of the following statement "students take advantages of the education process which brings them sufficient teaching experience"; it can be stated that utility in the process of education has a vital importance. To ensure the utility, the traditional approaches which are embraced in the educational organization must be left behind and democratic approaches must be embraced. More and more freedoms in the educational organization must be embraced. Inhibition that is seen in the educational organization must be annihilated. Also, merging interior and exterior factors under the democratic organization must be systematized (Demirel, 2017).

When the research topic is evaluated from the viewpoint of the following statement:

"during their education, students experience many fascinating features related to teaching professions which they haven't seen before "it is expected that the students must have good habits and new life styles after they start in their education. Educational institutions must create some positive facilities in the life of preservice teachers and it must provide opportunities which they don't have before they start in their education to the preservice teachers.

It is clearly seen that providing opportunities and facilities in a fair and balanced way is really important, when the research topic is evaluated from the viewpoint of the following statement "opportunities and facilities that the students have in the school let them have rich variety of experiences related to communication with people. "Opportunities and facilities in the educational organizations must be parallel with each other. Providing opportunities to the preservice teachers doesn't make sense, but providing opportunities and facilities at the same time can be seen worthwhile. Opportunities must be equipped with facilities. The facilities and opportunities that are provided for preservice teachers make them have many different values. Having ability of communication with the other people can be counted as one of these values (Bursalığlu, 1987).

When the topic is investigated from the viewpoint of the following statement "the students who have thought that they couldn't be teacher understand they are in wrong to assume it after they experience teaching"; it can be observed that education help preservice teachers gain self-confidence. Educational organization make the people have moral courage and it help people around itself see the system valuable. Thanks to this positive situation, it should not be forgotten that factors related to public add positive values in terms of positive contributions (Başaran, 1985).

It can be said that undergraduate education has a vital importance when the topic is investigated from the viewpoint of the following statement "lecturers have enough professional competence since they have received decent undergraduate education." It is beyond dispute that undergraduate education can be called as the fundamental determinant of someone's profession. It must be accepted that the undergraduate education of both preservice teachers and the lecturers who are responsible for training them is important. If the lecturers haven't received decent undergraduate education, it is not possible that they become successful in the educational organization, they train preservice teachers in a required way and they convey the field knowledge to the preservice teachers.

When the topic is analyzed from the viewpoint of the following "lecturers can convey their knowledge to students by showing their class related to class management and employing different methods to teach since they don't teach the lessons with the exception of their professional fields."; it has an vital importance that the lecturers must teach the lessons which are in the scope of their field of specialization. When the lecturers teach the lessons which are in the scope of their field of specialization, it strengthen their self-confidence. When they teach the lessons which are in the scope of their field of specialization, it raises the possibility of using their class management skills effectively. Also, the lecturer who teaches the courses related to his/her field of specialization has a chance to create a different environment in the class by employing different methods (Taymaz, 1981).

When the research topic is evaluated from the viewpoint of the following statement "lecturers can plan the teaching-learning process successfully thanks to their professional teaching knowledge."; that the lecturers have professional teaching knowledge has vital importance can be said. Lecturer trained in the professional teaching field must receive decent education both in their own field and in the field of liberal education. It is possible that a lecturer trained like this can create a good educational plan (Adem, 1981).

Akan and Ataş (2014) it has been mentioned in Tuan et al. (2005) that it is important to make students acquire cognitive properties as well as affective properties in today's educational system. It has been reported in studies of Duit and Treagust (2003), Tuan et al. (2005), Dede and Yaman (2008) that affective field skills are an important factor in making students become successful. Therefore, there are increasing changes in educational systems 
together with changes in technology, economy, and social life, impacted by globalization. As Orhan-Karsak (2017) and Sahlberg (2006) discussed, policies. Another important idea is that productive utilization of instructional materials-electronic systems, tools, equipment, consumable and others are essential for inculcating and developing functional knowledge and skills in the learners (Owoh, 2016). Making electronic information resources available in school libraries is to enhance teaching and learning. Electronic information resources are special library resources adopted in the contemporary information age (Bello et al., 2015). Teachers should develop strategies for enhancing communication and computational skills among their students and students should be enlightened on the relevance of communication and computational skills to their academic performance (Chadi, 2017).

When the topic is considered from the viewpoint of the following statement "scientific dignity that the lecturers have thanks to their competence makes them reach the exemplary positions"; that the preservice teachers have the goods and scientific dignity that they gain from their goods come into great prominence. AYIK and ATAŞ (2014) in that way, it is possible that a lecturer who has the goods fulfill an exemplary position in the educational organization.

When the topic is considered from the viewpoint of the following statement "the high level of service delivery qualifications which the lecturers have thanks to their competence makes the students apply their knowledge to real life."; it is possible that lecturers who are competent can perform more qualified services. The valuable knowledge conveyed by the competent lecturers can be used by the preservice teachers in real life. Similarly, it makes that lecturers keep under the practical supervision in the educational organization easier (Kaya, 1993).

\section{Methods}

The research was designed according to the descriptive survey method of qualitative research methods. Qualitative Descriptive Study is a descriptive study designed according to the naturalistic paradigm in which data is not examined or interpreted in depth such as in phenomenology, grounded theory, ethnography studies, but social events and facts are presented originally through interviews, observations, document examination methods (Lambert and Lambert, 2012; Walker, 2012; Arslantürk and Arslantürk, 2013).

The scope of questionnaires used as data gathering tool for the attitude of preservice teachers of Ağrı İ.Ç. University Faculty of Education who study at the Department of Elementary Turkish Education to the statements related to A-)The statements related to preservice teachers, B-)The statements related to competence of lecturers has been developed pursuant to the objective of the research. Prepared questionnaires have been adapted into data processing technique by conferring with the opinions of the personnel who are knowledgeable about this topic. Trial forms prepared within this framework are applied to two different groups in the A $\breve{r}$ I İ.Ç. University Faculty of Education. According to findings which are obtained from trial forms, it is proved that certain questions have failed to be operational. In order to establish validity which shows the expediency degree of a measurement tool and reliability which shows the consistency criterion of an measurement tool, non-operational questions have been excluded from the questionnaire form. After these processes, the scope and form questionnaires have been given its final shape. The information gathered from the questionnaire distributed to preservice teachers of A $\breve{g} r$ İ.Ç. University Faculty of Education who study at the Department of Elementary Turkish Education, is analyzed in terms of research objective and it is attempted to draw a conclusion in that way. Before drawing the conclusions of the research, data gathered through the questionnaires has been transformed into certain tables by the researcher. These tables which are mentioned make it easy to draw a conclusion. The preservice teachers of A $\breve{g r}$ İ.Ç. University Faculty of Education who study at the Department of Elementary Turkish Education who participate in the questionnaire are asked to grade accuracy level related to their point of view on the statements related to A) The statements related to preservice teachers, B) The statements related to competence of lecturers as "Strongly disagree"," Disagree", "Neutral/Neither agree nor disagree”," Agree”," Strongly agree”. These degrees are graded, respectively, 1, 2, 3,4 and 5 . In this way, degrees of accuracy are converted into percentages.

\subsection{Universe and Sampling}

Research universe consists of preservice teachers of A ğrı İ.Ç. University Faculty of Education who study at the Department of Elementary Turkish Education. List of the preservice teachers of A $\breve{g}_{r ı}$ İ.Ç. University Faculty of Education who study at the Department of Elementary Turkish Education is used as the ground of detecting the universe. Since the main criterion has been to reach a majority of the preservice teachers, it is possible to claim that sampling is a reflection of the universe. This research is conducted on a group consisting of 121 preservice teachers of Ağrı I.Ç. University Faculty of Education who study at the Department of Elementary Turkish Education. It is aimed at including preservice teacher of A ğrı İ.Ç. University Faculty of Education who study at the Department of Elementary Turkish Education within the sampling, the aim is achieved substantially. Also, the fractions of numbers are not recorded on the charts while numbering the percentages of the research. If there are tables in which the rate of a $100 \%$ is not reach or if there is a lack of total number of "Positive Choices" namely "Agree" and "Totally Agree", the lack of fractional numbers can be seen as the reason of them.

\subsection{Data Collection}

The data obtained in the study were analyzed through descriptive analysis. Descriptive analysis is the analysis of data according to the preliminarily established theoretical framework or the sketch or temporary code scheme obtained in parallel with the variables obtained through observations and interviews in relation to the questionnaire based on the literature (Yıldırım and Şimşek, 2013; Creswell, 2015; Huberman and Miles, 2015).

Questionnaire has been answered by all of the 121 preservice teachers. None of the questionnaires which have been answered by the participants are invalid. The questionnaire is answered by nearly all of the preservice teachers of Ağrı İ.Ç. University Faculty of Education who study at the Department of Elementary Turkish Education. The participants have been requested to complete the questionnaires appropriately prior to submission. The preservice teachers have been asked to fill the forms in due form and hand in to the researcher. 


\subsection{Problem}

The present study aims at finding out on what level the point of views of the preservice teachers of Ağrı I.Ç. University Faculty of Education who study at the Department of Elementary Turkish Education on the statements related to A-) The statements related to preservice teachers and B-) The statements related to competence of lecturers

\subsection{Sub-Problem}

What is the level of perspectives of the preservice teachers of Ağrı İ.Ç. University Faculty of Education who study at the Department of Elementary Turkish Education on the statements related to A-) The statements related to preservice teachers and $\mathrm{B}-$ ) The statements related to competence of lecturers?

\subsection{Hypothesis}

The level of viewpoints of the preservice teachers of Ağrı İ.Ç. University Faculty of Education who study at the Department of Elementary Turkish Education on the statements related to A-) The statements related to preservice teachers and B-) The statements related to competence of lecturers is in "desired" level.

\subsection{Premises}

1. Pre-testing for developing the questionnaires is sufficient.

2. Expert views taken to developed the surveys are sufficient.

3. The views of the preservice teachers of Ağrı İ.Ç. University Faculty of Education who study at the Department of Elementary Turkish Education consulted in the research reflect the reality.

4. Selected research method is compatible with the objective of research.

5. The sample's degree of representing the population is in the favorable level.

6. The questionnaire and the questions in the survey which have been used to gather data are valid and reliable.

7. The fact that the data obtained by survey is valid and reliable is acceptable.

\subsection{Restrictions}

1. This research is limited to perspectives of the preservice teachers of Ağrı İ.Ç. University Faculty of Education who study at the Department of Elementary Turkish Education.

2. This research is limited to resources which are accessible and surveys which are used as data gathering tool.

\section{Findings}

In this section, perspectives of the preservice teachers of Ağrı İ.Ç. University Faculty of Education who study at the Department of Elementary Turkish Education on the statements related to A-)The statements related to preservice teachers and B-) The statements related to competence of lecturers are given through the tables. To determine the perspectives of preservice teachers on the statements related to A-) The statements related to preservice teachers and B-) The statements related to competence of lecturers, preservice teachers are asked to grade their point of view on these topics as "Strongly disagree", "Disagree", "Neutral/Neither agree nor disagree", "Agree", "Strongly agree". As mentioned before, these degrees are graded, respectively, 1, 2, 3,4 and 5. Perspectives of preservice teachers on A-) The statements related to preservice teachers and B-) The statements related to competence of lecturers are shown by the help of the tables. In this research, "Agree" and "Totally Agree " is accepted as the positive choices which have high levels of realization.

\section{A-) The Statements Related to Preservice Teachers:}

Table-1. Productivity of the courses taken in the school enable them to understand the qualifications that a teacher must have.

\begin{tabular}{|c|c|c|c|c|c|}
\hline & & Frequency & Percent & Valid Percent & Cumulative Percent \\
\hline \multirow[t]{6}{*}{ Valid } & Strongly disagree & 2 & 1,7 & 1,7 & 1,7 \\
\hline & Disagree & 20 & 16,5 & 16,5 & 18,2 \\
\hline & Neutral & 15 & 12,4 & 12,4 & 30,6 \\
\hline & Agree & 51 & 42,1 & 42,1 & 72,7 \\
\hline & Totally Agree & 33 & 27,3 & 27,3 & 100,0 \\
\hline & Total & 121 & 100,0 & 100,0 & \\
\hline
\end{tabular}

Source: Data have obtained from authors' field study.

As seen in the Table 1, there are 2 of the preservice teachers who have chosen "Strongly disagree", 20 of them have chosen "Disagree", 15 of these preservice teachers have chosen "Neutral", 51 of the preservice teachers have chosen "Agree", 33 of them have chosen "Totally Agree". The expectations of $69 \%$ of the preservice teachers (26 preservice teachers) on this issue are in positive choices (regarding the sum of "Agree" and "Totally Agree" options). 
Table-2. Students take advantages of the education process which brings them sufficient teaching experience.

\begin{tabular}{l|l|c|c|c|c}
\hline \multicolumn{2}{l|}{} & Frequency & Percent & Valid Percent & Cumulative Percent \\
\hline \multirow{7}{*}{ Valid } & Strongly disagree & 10 & 8,3 & 8,3 & 8,3 \\
\cline { 2 - 6 } & Disagree & 48 & 39,7 & 39,7 & 47,9 \\
\cline { 2 - 5 } & Neutral & 27 & 22,3 & 22,3 & 70,2 \\
\cline { 2 - 5 } & Agree & 28 & 23,1 & 23,1 & 93,4 \\
\cline { 2 - 5 } & Totally Agree & 8 & 6,6 & 6,6 & 100,0 \\
\cline { 2 - 5 } & Total & 121 & 100,0 & 100,0 & \\
\hline
\end{tabular}

Source: Data have obtained from authors' field study.

As seen in the Table 2, there are 10 of the preservice teachers who have chosen "Strongly disagree", 48 of them have chosen "Disagree", 27 of these preservice teachers have chosen "Neutral", 28 of the preservice teachers have chosen "Agree", 8 of them have chosen "Totally Agree". The expectations of $29 \%$ of the preservice teachers (36 preservice teachers) on this issue are in positive choices (regarding the sum of "Agree" and "Totally Agree" options).

Table-3. During their education, students experience many fascinating features related to teaching professions which they haven't seen before.

\begin{tabular}{l|l|c|c|c|c}
\hline & Frequency & Percent & Valid Percent & Cumulative Percent \\
\hline \multirow{3}{*}{ Valid } & Strongly disagree & 4 & 3,3 & 3,3 & 3,3 \\
\cline { 2 - 6 } & Disagree & 16 & 13,2 & 13,2 & 16,5 \\
\cline { 2 - 6 } & Neutral & 12 & 9,9 & 9,9 & 26,4 \\
\cline { 2 - 6 } & Agree & 63 & 52,1 & 52,1 & 78,5 \\
\cline { 2 - 6 } & Totally Agree & 26 & 21,5 & 21,5 & 100,0 \\
\cline { 2 - 6 } & Total & 121 & 100,0 & 100,0 & \\
\hline
\end{tabular}

As given in the Table 3, there are 4 of the preservice teachers who have chosen "Strongly disagree", 16 of them have chosen "Disagree", 12 of these preservice teachers have chosen "Neutral", 63 of the preservice teachers have chosen "Agree", 26 of them have chosen "Totally Agree". The expectations of $73 \%$ of the preservice teachers ( 89 preservice teachers) on this issue are in positive choices (regarding the sum of "Agree" and "Totally Agree" options).

Table-4. Opportunities and chances that the students have in the school let them have rich variety of experiences related to communication with people.

\begin{tabular}{l|l|c|c|c|c}
\hline \multicolumn{2}{l|}{ Valid } & Frequency & Percent & Valid Percent & Cumulative Percent \\
\cline { 2 - 6 } & Strongly disagree & 5 & 4,1 & 4,1 & 4,1 \\
\cline { 2 - 6 } & Disagree & 12 & 9,9 & 9,9 & 14,0 \\
\cline { 2 - 6 } & Neutral & 9 & 7,4 & 7,4 & 21,5 \\
\cline { 2 - 6 } & Agree & 68 & 56,2 & 56,2 & 77,7 \\
\cline { 2 - 6 } & Totally Agree & 27 & 22,3 & 22,3 & 100,0 \\
\cline { 2 - 6 } & Total & 121 & 100,0 & 100,0 & \\
\hline
\end{tabular}

Source: Data have obtained from authors' field study.

As given in the Table 4, there are 5 of the preservice teachers who have chosen "Strongly disagree", 12 of them have chosen "Disagree", 9 of these preservice teachers have chosen "Neutral", 68 of the preservice teachers have chosen "Agree", 27 of them have chosen "Totally Agree". The expectations of $78 \%$ of the preservice teachers (95 preservice teachers) on this issue are in positive choices (regarding the sum of "Agree" and "Totally Agree" options).

Table-5. The students who have thought that they couldn't be teacher understand they are in wrong to assume it after they experience teaching.

\begin{tabular}{l|l|c|c|c|c}
\hline \multicolumn{2}{|c|}{} & Frequency & Percent & Valid Percent & Cumulative Percent \\
\hline \multirow{5}{*}{ Valid } & Strongly disagree & 6 & 5,0 & 5,0 & 5,0 \\
\cline { 2 - 6 } & Disagree & 24 & 19,8 & 19,8 & 24,8 \\
\cline { 2 - 6 } & Neutral & 28 & 23,1 & 23,1 & 47,9 \\
\cline { 2 - 6 } & Agree & 48 & 39,7 & 39,7 & 87,6 \\
\cline { 2 - 6 } & Totally Agree & 15 & 12,4 & 12,4 & 100,0 \\
\cline { 2 - 6 } & Total & 121 & 100,0 & 100,0 & \\
\hline
\end{tabular}

Source: Data have obtained from authors' field study.

As evaluated in the Table 5, there are 6 of the preservice teachers who have chosen "Strongly disagree", 24 of them have chosen "Disagree", 28 of these preservice teachers have chosen "Neutral", 48 of the preservice teachers have chosen "Agree", 15 of them have chosen "Totally Agree". The expectations of $51 \%$ of the preservice teachers (63 preservice teachers) on this issue are in positive choices (regarding the sum of "Agree" and "Totally Agree" options). 
B-) The Statements Related to Competence of Lecturers:

Table-1. Lecturers have enough professional competence since they have received decent undergraduate education.

\begin{tabular}{l|l|c|c|c|c}
\hline \multicolumn{2}{l|}{ Valid } & Frequency & Percent & Valid Percent & Cumulative Percent \\
\cline { 2 - 6 } & Disagree & 14 & 11,6 & 11,6 & 11,6 \\
\cline { 2 - 6 } & Neutral & 53 & 43,8 & 43,8 & 55,4 \\
\cline { 2 - 6 } & Agree & 26 & 21,5 & 21,5 & 76,9 \\
\cline { 2 - 6 } & Totally Agree & 26 & 21,5 & 21,5 & 98,3 \\
\cline { 2 - 5 } & Total & 121 & 1,7 & 1,7 & 100,0 \\
\hline
\end{tabular}

Source: Data have obtained from authors' field study.

As evaluated in the Table 1, there are 14 of the lecturers who have chosen "Strongly disagree", 53 of them have chosen "Disagree", 26 of these lecturers have chosen "Neutral", 26 of the lecturers have chosen "Agree", 2 of them have chosen "Totally Agree". The expectations of $22 \%$ of the lecturers (28 lecturers ) on this issue are in positive choices (regarding the sum of "Agree" and "Totally Agree" options).

Table-2. Lecturers can convey their knowledge to students by showing their class related to class management and employing different methods to teach since they don't teach the lessons with the exception of their professional fields.

\begin{tabular}{|c|c|c|c|c|c|}
\hline & & Frequency & Percent & Valid Percent & Cumulative Percent \\
\hline \multirow[t]{6}{*}{ Valid } & Strongly disagree & 19 & 15,7 & 15,7 & 15,7 \\
\hline & Disagree & 34 & 28,1 & 28,1 & 43,8 \\
\hline & Neutral & 27 & 22,3 & 22,3 & 66,1 \\
\hline & Agree & 35 & 28,9 & 28,9 & 95,0 \\
\hline & Totally Agree & 6 & 5,0 & 5,0 & 100,0 \\
\hline & Total & 121 & 100,0 & 100,0 & \\
\hline
\end{tabular}

Source: Data have obtained from authors' field study.

As given in the Table-2, there are 19 of the lecturers who have chosen "Strongly disagree", 34 of them have chosen "Disagree", 27 of these lecturers have chosen "Neutral", 35 of the lecturers have chosen "Agree", 6 of them have chosen "Totally Agree". The expectations of $33 \%$ of the lecturers (41 lecturers) on this issue are in positive choices (regarding the sum of "Agree" and "Totally Agree" options).

\begin{tabular}{|c|c|c|c|c|c|}
\hline & & Frequency & Percent & Valid Percent & Cumulative Percent \\
\hline \multirow[t]{6}{*}{ Valid } & Strongly disagree & 6 & 5,0 & 5,0 & 5,0 \\
\hline & Disagree & 25 & 20,7 & 20,7 & 25,6 \\
\hline & Neutral & 36 & 29,8 & 29,8 & 55,4 \\
\hline & \begin{tabular}{|l|} 
Agree \\
\end{tabular} & 44 & 36,4 & 36,4 & 91,7 \\
\hline & \begin{tabular}{|l|} 
Totally Agree \\
\end{tabular} & 10 & 8,3 & 8,3 & 100,0 \\
\hline & Total & 121 & 100,0 & 100,0 & \\
\hline
\end{tabular}

Source: Data have obtained from authors' field study.

As seen in the Table-3, there are 6 of the lecturers who have chosen "Strongly disagree", 25 of them have chosen "Disagree", 36 of these lecturers have chosen "Neutral", 44 of the lecturers have chosen "Agree", 10 of them have chosen "Totally Agree". The expectations of $44 \%$ of the lecturers (54 lecturers) on this issue are in positive choices (regarding the sum of "Agree" and "Totally Agree" options).

Table-4. Scientific dignity that the lecturers have thanks to their competence makes them reach the exemplary positions.
\begin{tabular}{l|l|c|c|c|c}
\hline \multirow{3}{*}{ Valid } & Frequency & Percent & Valid Percent & Cumulative Percent \\
\cline { 2 - 6 } & Strongly disagree & 14 & 11,6 & 11,6 & 11,6 \\
\cline { 2 - 5 } & Disagree & 34 & 28,1 & 28,1 & 39,7 \\
\cline { 2 - 5 } & Neutral & 23 & 19,0 & 19,0 & 58,7 \\
\cline { 2 - 5 } & Agree & 39 & 32,2 & 32,2 & 90,9 \\
\cline { 2 - 5 } & Totally Agree & 11 & 9,1 & 9,1 & 100,0 \\
\cline { 2 - 5 } & Total & 121 & 100,0 & 100,0 & \\
\hline
\end{tabular}

Source: Data have obtained from authors' field study.

As seen in the Table-4, there are 14 of the lecturers who have chosen "Strongly disagree", 34 of them have chosen "Disagree", 23 of these lecturers have chosen "Neutral", 39 of the lecturers have chosen "Agree", 11 of them have chosen "Totally Agree". The expectations of $41 \%$ of the lecturers (50 lecturers) on this issue are in positive choices (regarding the sum of "Agree" and "Totally Agree" options).

Table-5. The high level of service delivery qualifications which the lecturers have thanks to their competence makes the students apply their knowledge to real life.

\begin{tabular}{|c|c|c|c|c|c|}
\hline & & Frequency & Percent & Valid Percent & Cumulative Percent \\
\hline \multirow[t]{6}{*}{ Valid } & Strongly disagree & 14 & 11,6 & 11,6 & 11,6 \\
\hline & Disagree & 38 & 31,4 & 31,4 & 43,0 \\
\hline & Neutral & 26 & 21,5 & 21,5 & 64,5 \\
\hline & \begin{tabular}{|l|} 
Agree \\
\end{tabular} & 31 & 25,6 & 25,6 & 90,1 \\
\hline & Totally Agree & 12 & 9,9 & 9,9 & 100,0 \\
\hline & Total & 121 & 100,0 & 100,0 & \\
\hline
\end{tabular}

Source: Data have obtained from authors' field study. 
As seen in the Table-5, there are 14 of the lecturers who have chosen "Strongly disagree", 38 of them have chosen "Disagree", 26 of these lecturers have chosen "Neutral", 31 of the lecturers have chosen "Agree", 12 of them have chosen "Totally Agree". The expectations of $34 \%$ of the lecturers (43 lecturers) on this issue are in positive choices (regarding the sum of "Agree" and "Totally Agree" options).

\section{Results}

1. The attitude of $69 \%$ preservice teachers (84 preservice teachers) to the statement that "productivity of the courses taken in the school enables them to understand the qualifications that a teacher must have." is in positive choices. It is seen that preservice teachers expect productivity from the courses taken in the school.

2. The attitude of $29 \%$ preservice teachers (36 preservice teachers) to the statement that "Students take advantages of the education process which brings them sufficient teaching experience" is in positive choices. The preservice teachers state that they can't benefit from the teaching process and they don't gain sufficient teaching experience.

3. The attitude of $73 \%$ preservice teachers (89 preservice teachers) to the statement that "during their education, students experience many fascinating features related to teaching professions which they haven't seen before." is in positive choices. This situation shows that preservice teachers experience many fascinating features related to teaching professions.

4. The attitude of $78 \%$ preservice teachers (95 preservice teachers) to the statement that "opportunities and chances that the students have in the school let them have rich variety of experiences related to communication with people." is in positive choices. The preservice teachers states that they gain experince related to communication through the some kinds of opportunities and facilities.

5. The attitude of $51 \%$ preservice teachers (63 preservice teachers) to the statement that "the students who have thought that they couldn't be teacher understand they are in wrong to assume it after they experience teaching" is in positive choices. It is highlighted that preservice teachers' thoughts related to teaching professions can change after they start in teaching-learning process.

6. The attitude of $22 \%$ lecturers (28 lecturers) to the statement "lecturers have enough professional competence since they have received decent undergraduate education" is in positive choices. This situation shows that preservice teachers believe that lecturers haven't received decent undergraduate education.

7. The attitude of $33 \%$ lecturers ( 41 lecturers) to the statement "lecturers can convey their knowledge to students by showing their class related to class management and employing different methods to teach since they don't teach the lessons with the exception of their professional fields." is in positive choices. This result shows that preservice teachers think that lecturers don't teach the lesson with the exception of their professional fields, they aren't good at managing class, they cannot convey their knowledge by the help of different methods.

8. The attitude of $44 \%$ lecturers (54 lecturers) to the statement that "lecturers can plan the teaching-learning process successfully thanks to their professional teaching knowledge" is in positive choices. This situation shows that preservice teachers think that lecturers can create educational planning in some degree.

9. The attitude of $41 \%$ lecturers (50 lecturers) to the statement that "scientific dignity that the lecturers have thanks to their competence makes them reach the exemplary positions." is in positive choices. This result shows that preservice teachers accept that the lecturer have goods with the ratio which is under $50 \%$.

10. The attitude of $34 \%$ lecturers (43 lecturers) to the statement that "the high level of service delivery qualifications which the lecturers have thanks to their competence makes the students apply their knowledge to real life" is in positive choices. This situation shows that preservice teachers believe that lecturers are competent, perform high level of service, convey knowledge which is given on to the life with the ratio which is under $50 \%$.

\section{Suggestions}

1. 1. Bearing in mind that attitude of $69 \%$ of the preservice teachers (84 preservice teachers) to the statement that "productivity of the courses taken in the school enable them to understand the qualifications that a teacher must have." is in positive choices, education organization should place the lecturers who have valuable features in the system and the educational organization should create opportunities for productivity in lessons.

2. As a consequence of the fact that attitude of $29 \%$ of preservice teachers (36 preservice teachers) to the statement that "students take advantages of the education process which brings them sufficient teaching experience" is in positive choices, educational administration must create practical applications to help the preservice teachers gain sufficient teaching professional experiences which let them take the advantages of the education process.

3. In view of the fact that attitude of $73 \%$ of preservice teachers (89 preservice teachers) to the statement that "during their education, students experience many fascinating features related to teaching professions which they haven't seen before" is in positive choices, educational administration must provide new perspectives that will not don't make them long for their past experiences.

4. As a result of the fact that attitude of $78 \%$ of preservice teachers (95 preservice teachers) to the statement that "opportunities and chances that the students have in the school let them have rich variety of experiences related to communication with people." is in positive choices, educational administration must carry on works which are parallel with the fact that the value of the school in the society is increased.

5. As a consequence of the fact that attitude of $51 \%$ of preservice teachers (63 preservice teachers) to the statement that "the students who have thought that they couldn't be teacher understand they are in wrong to assume it after they experience teaching" is in positive choices, educational administration which must realize the importance of education in increasing the self-confidence of people and it must help increase the self-confidence of the people. 
6. In view of the fact that attitude of $22 \%$ lecturers ( 28 preservice teachers) to the statement that "lecturers have enough professional competence since they have received decent undergraduate education." is in positive choices, it can be a guiding light to make educational administration organization the importance of decent undergraduate education.

7. Bearing in mind that attitude of $33 \%$ of lecturers (41 lecturers) to the statement that "lecturers can convey their knowledge to students by showing their class related to class management and employing different methods to teach since they don't teach the lessons with the exception of their professional fields." is in positive choices, educational administration organization shouldn't let the lecturers teach the lessons which are not with the exception of their professional fields.

8. As a result of the fact that attitude of $44 \%$ of lecturers(54 lecturers) to the statement that "lecturers can plan the teaching-learning process successfully thanks to their professional teaching knowledge "is in positive choices, educational administration organization must continue to attach importance to being planful in the education.

9. As a consequence of the fact that attitude of 41 of lecturers (50 lecturers) to the statement that "scientific dignity that the lecturers have thanks to their competence makes them reach the exemplary positions" is in positive choices, it should be a guiding light that remind the lecturers that they shouldn't give up having goods.

10. In view of the fact that attitude of $34 \%$ (43 lecturers) to the statement that" the high level of service delivery qualifications which the lecturers have thanks to their competence makes the students apply their knowledge to real life" is in positive choices, this results must make the lecturers be aware towards competence, performing high level of service, conveying knowledge given on to the real life.

\section{References}

Adem, M., 1981. Planning of training. Ankara: Sevinç Printing Press.

Akan, D. and Ö. Ataş, 2014. Having a virtuous teacher to have moral virtues. Scholars Journal of Arts, Humanities and Social Sciences, 2(2B): 298-304.

Arslantürk, Z. and H.E. Arslantürk, 2013. Applied social research spss, concepts, techniques, methods, computer applications. İstanbul: Çamlıca Publishing.

AYIK, A. and Ö. ATAŞ, 2014. The relationship between teacher candidates' attitudes towards teaching profession and teaching motivations. Journal of Educational Sciences Research, 4(1): 25-43.Available at: https://doi.org/10.12973/jesr.2014.41.2.

Başaran, İ.E., 1985. Management of occupational services in organizations. Ankara: Ankara University Press.

Bello, S.A., F.R. Ojo and C.B. Ocheje, 2015. Effective knowledge development in secondary schools educational level in contemporary information age: Assessment of availability of electronic information resources in Nigerian school libraries. Journal of Education and e-Learning Research, 2(4): 72-78.

Bursalığlu, Z., 1987. New structure and behavior in school management. 7th Edn., Ankara: Ankara University Education Faculty Press.

Chadi, A.M., 2017. Relationship between nce iii business education students computational skill and their cumulative grade point average (cgpa) in colleges of education in bauchi and gombe states. Journal of Education and e-Learning Research, 4(3): 118-121.Available at: https://doi.org/10.20448/journal.509.2017.43.118.121.

Creswell, J.W., 2015. 3rd Edn., Qualitative research methods. (Tra. Ed. M. Bütün ve S. B. Demir). 3rd Edn., Ankara-Turkey: Siyasal Bookstore. pp: 27.

Dede, Y. and S. Yaman, 2008. Motivation scale for science learning: Validity and reliability study. Necatibey Education Faculty Electronic Journal of Science and Mathematics Education (EFMED), 2(1): 19-37.

Demirel, İ.N., 2017. Education management inspection planning and economics with 100 questions. 8th Edn., Ankara: Minel Publishing.

Duit, R. and D.F. Treagust, 2003. Conceptual change: A powerful framework for improving science teaching and learning. International Journal of Science Education, 25(6): 67 1-688.Available at: https://doi.org/10.1080/09500690305016.

Field, A., 2013. Discovering statistics using IBM SPSS statistics. London, UK: Sage Publications.

Huberman, M.A. and M.B. Miles, 2015. Qualitative data analysis. 2nd Edn., Ankara: Pegem Academy.

Kaya, Y.K., 1993. Management of training. 5th Edn., Ankara: Bilim Publishing, Developed.

Lambert, V.A. and C.E. Lambert, 2012. Qualitative descriptive research: An acceptable design. Pacific Rim International Journal of Nursing Research, 16(4): 255-256.

Orhan-Karsak, H.G., 2017. Reflections of the Changing Education System According to the Views of School Managers: Turkey Sample. Universal Journal of Educational Research, 5(8): 1308-1322.Available at: https://doi.org/10.13189/ujer.2017.050804.

Owoh, T.M., 2016. Development of employable skills in vocational education by the utilization of instructional materials. Journal of Education and e-Learning Research, 3(4): 139-143.Available at: https://doi.org/10.20448/journal.509/2016.3.4/509.4.138.142.

Sahlberg, P., 2006. Education reform for raising economic competitiveness. Journal of Educational Change, 7(4): 259-287.Available at: https://doi.org/10.1007/s 10833-005-4884-6.

Taymaz, H., 1981. In-service training. Ankara: A.U. Education Faculty Press.

Tuan, H.-L., C.-C. Chin and S.-H. Shieh, 2005. The development of a questionnaire to measure students' motivation towards science learning. International Journal of Science Education, 27(6): 639-654.Available at: https://doi.org/10.1080/0950069042000323737.

Walker, R., 2012. Naturalistic research, research methods and methodologies in education. California: Sega.

Yıldırım, A. and H. Şimşek, 2013. Qualitative research methods in the social sciences. Ankara: Seçkin Publishing.

Yildirim, S. and M.A. Haşıloğlu, 2018. Analysis of scientific research related anxiety levels of undergraduate students. Universal Journal of Educational Research, 6(2): 313-316.Available at: https://doi.org/10.13189/ujer.2018.060214. 